\title{
Ortaöğretim Öğrencilerinin Metalik Bağ ile ilgili Algıları, Metalik Bağı Tanımlamada Kullandıkları Metaforlar ve Yaptıkları Benzeşimler ${ }^{1}$
}

\section{Secondary School Students' Perceptions about Metallic Bond, Metaphors Used in Definition of Metallic Bond and their Analogies}

\author{
Canan NAKİBOĞLU², Şafak YILDIRIM ${ }^{3}$
}

\begin{tabular}{|c|c|}
\hline $\begin{array}{l}\text { Anahtar Kelimeler } \\
\text { Ortaöğretim } \\
\text { ögrencileri, } \\
\text { Metalik ba } \breve{g}, \\
\text { Metafor, } \\
\text { Benzeşim. }\end{array}$ & 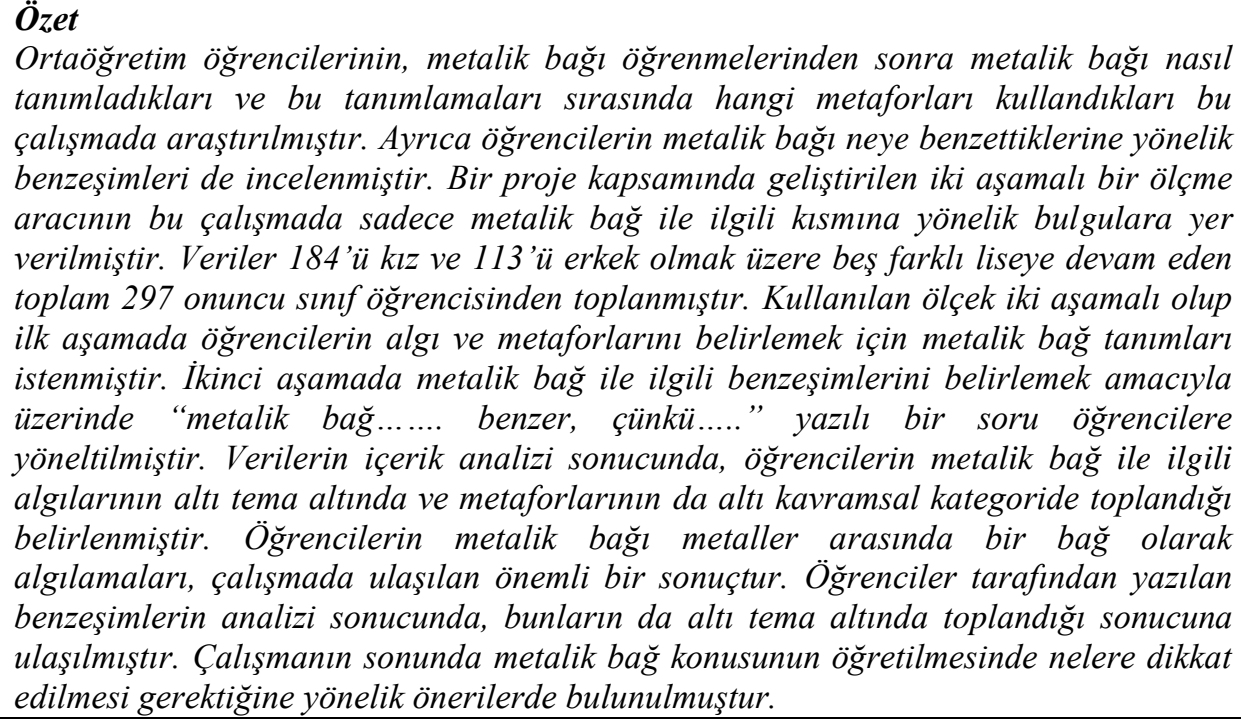 \\
\hline $\begin{array}{l}\frac{\text { Key Word }}{\text { Secondary school }} \\
\text { students, } \\
\text { Metallic bond, } \\
\text { Metaphors, } \\
\text { Analogies. }\end{array}$ & $\begin{array}{l}\text { Abstract } \\
\text { In this study, how secondary school students define metallic bonds after learning } \\
\text { metallic bonds, and which metaphors they use during their definitions were } \\
\text { investigated. Also, the analogies of the students about the metallic bond are examined. } \\
\text { In this study, only findings related to the metallic bond of a two-stage measuring } \\
\text { instrument developed within the scope of a project are included. Data were collected } \\
\text { from } 297 \text { tenth grade students attending five different high schools, } 184 \text { girls and } 113 \\
\text { boys. The instrument used was two-stage, and in the first stage, the definitions of the } \\
\text { metallic bond were asked to determine the students' perception and metaphors. In the } \\
\text { second stage, a question containing the statement "metallic bond is like...... because } \\
\text {...." was given to the students to obtain their analogies about the metallic bond. As a } \\
\text { result of the content analysis of the data, it was determined that students' perceptions } \\
\text { about metallic bond were collected under six themes, and metaphors were collected in } \\
\text { six conceptual categories. It is an essential result of the study that students perceive } \\
\text { metallic bond like a bond between metals. After the similarities written by the students } \\
\text { were analysed, it was decided that the analogies of the students were collected under } \\
\text { six themes. At the end of the study, the recommendations were made about what should } \\
\text { be considered in teaching metallic bonding. }\end{array}$ \\
\hline
\end{tabular}

Attfiçin: Nakiboğlu, C. \& Yıldırım, Ş. (2020). Ortaöğretim Öğrencilerinin Metalik Bağ ile ilgili

For Citation Algıları, Metalik Bağı Tanımlamada Kullandıkları Metaforlar ve Yaptıkları Benzeşimler.

Muğla Sitkı Koçman Üniversitesi Ĕgitim Fakültesi Dergisi [MSKU Journal of Education],

7(1), 1-11. DOI: 10.21666/muefd.660211

Received: 17.12.2019 Accepted: $18.03 .2020 \quad$ Published: 01.05.2020

\footnotetext{
${ }^{1}$ Bu çalışma Şafak Yıldırım'ın yüksek lisans tez çalışmasından üretilmiştir.

${ }^{2}$ Balıkesir Üniversitesi Necatibey Eğitim Fakültesi, canan@balikesir.edu.tr, ORCID: 0000-0002-7292-9690

${ }^{3}$ Balıkesir Üniversitesi Fen Bilimleri Enstitüsü, safakimya@gmail.com, ORCID: 0000-0001-7298-8095
} 
Ortaöğretim öğrencilerinin kimya kavramları ile ilgili önemli sorunlar yaşadığ nedenlerinden birisi kimyanın gözle görülemeyen ve duyularla algılamayan atom, iyon ve molekül gibi tanecikler ile bunların arasında gerçekleşen olaylar içermesidir. Bunların anlaşılması için kavram öğretimi son derece önemli olup özellikle öğrenciler tarafından kimyanın temel kavramlarının iyi anlaşılarak aralarındaki ilişkilerin doğru kurulması gerekir. Kimyanın temel konularına baktığımızda atom ve bunlar arasındaki etkileşimler yani madde oluşumu en temel konudur. Madde oluşumunun ve maddeler arasındaki etkileşimlerin öğrenciler tarafından anlamlı şekilde öğrenilmesi için de kimyasal bağlanmanın doğru anlaşılması gerekir. Öğrencilerin kimyasal bağların tür ve oluşum biçimlerini kavrayamamaları maddede meydana gelen değişimleri kimyasal bağlarla ilişkilendirmede güçlük yaşamalarına neden olmaktadır (Nakiboğlu \& Erol, 2017). Diğer taraftan kimyasal bağlanma başta olmak üzere iyonik, kovalent ve metalik bağların tümü ile ilgili liseden üniversiteye her düzeydeki öğrencinin anlama güçlüğü ve yanlış kavramalara sahip olduğu birçok araştırmacı tarafindan bildirilmiştir (Coll \& Taylor 2002; Kabapınar \& Adik, 2005; Nakiboğlu \& Yıldırım, 2019; Taber, Tsaparlis, \& Nakiboğlu, 2012). Yapılan çalışmalar incelendiğinde iyonik ve kovalent bağlanma konusunda çok fazla çalışma olmasına rağmen metalik bağlanma konusundaki çalışmaların nispeten sinırl1 olduğu görülür (Cheng \& Gilbert, 2014; Cheng \& Oon, 2016; Coll \& Treagust, 2003; de Posada, 1997 ve 1999; Nakiboğlu, 2019; Redfors, 2001; Taber, 2003).

Metalik bağlanma, metallerin özellikleri, metalik iletkenlik, yarı iletkenler gibi konularının iyi anlaşılmasında son derece önemli olup öğretilmesi sırasında farklı modeller ve metaforlardan yararlanılır. Bu nedenle metalik bağlara yönelik az sayıda yapılan çalışmalarda özellikle metalik bağların öğretiminde kullanılan modellere yönelik öğrencilerin geliştirdiği zihinsel modeller incelenmiş̧ir. Metalik bağlara yönelik zihinsel model çalışmaları ile ilgili ilk çalışmalar Coll ve Treagust (2003) ile Taber (2003) tarafından gerçekleştirilmiştir. Coll ve Treagust (2003), Yeni Zellandalı ortaöğretim, üniversite ve lisansüstü öğrencilerin metalik bağlarla ilgili zihinsel modellerini incelemişlerdir. $\mathrm{Bu}$ çalışma sonunda ortaöğretim öğrencilerinin metalik bağlanma ile ilgili en fazla "elektron-denizi" modelini tercih ettikleri belirlenmiştir. Bazı öğrencilerin metalik bağ için kovalent bağa benzer bir modele sahip oldukları belirlenirken bazı öğrencilerin de tanecikli yapı yerine metallerin makroskopik fiziksel özelliklerini içeren tanımlar yaptıkları görülmüştür. Üniversite ve lisansüstü düzeyinde de öğrencilerin "elektron-denizi” modelini tercih ettikleri, üniversite düzeyindeki öğrencilerin açıklamalarının daha ayrıntılı olduğu görülürken lisansüstü düzeydeki öğrencilerin bu modele yönelik lise öğrencilerinden daha eksiksiz açıklamalar yaptıkları belirlenmiştir. İki lisansüstü öğrencisinden birisi bilmediğini belirtirken, bir tanesi de metal atomları arasında gerçekten bir bağ olduğunu düşünmediğini ifade etmiştir.

Taber (2003) ise A-seviye öğrencilerinin öğretim öncesi ve sonrası metalik bağ ile ilgili zihinsel modellerini belirlemeye çalışmıştır. Öğretim öncesi öğrencilerin bir kısmının metallerde bağlanma olmadığı veya bir tür bağlanmanın olduğu ama bunun gerçek bir bağlanma olmadığını düşündüklerini belirlemiştir. Öğretimin sonunda öğrencilerin metalik bağ farklı bir bağ olarak düşünmeye başladıklarını ve metal katyon örgüsündeki elektrostatik etkileşimleri ifade ettikleri sonucuna ulaşmı̧sıtır.

Son y1llarda metalik bağlara yönelik yürütülen çalışmalardan birisisinde Cheng ve Gilbert (2014), öğrencilerin metalik bağ ile ilgili zihinsel modellerini ve metallerin dövülebilirliği ile ilgili düşüncelerini nitel bir çalışma ile derinlemesine incelemiştir. Çalışma sonunda her ne kadar öğrenciler metalik bağ tanımını yazabilseler de, bu tanımlamaya uygun bilimsel gösterimleri çizemediklerini ortaya koymuşlardır.

Nakiboğlu (2019), kimya öğretmen adaylarının metalik yapıya yönelik zihinsel modelleri ile metalik bağlanma ile ilgili kavramalarını incelemiştir. Çalışmanın sonunda öğretmen adaylarının metalik yapı ile ilgili zihinsel modellerinin yedi farklı grup altında toplandığını belirlemiştir. Bu modellerden biri "basit parçacık" modelinin hala önemli bir düzeyde öğrenci zihninde yer alması, öğretmen adaylarının ortaokul düzeyinde gördükleri basit modellerin hala etkisinde kaldığını göstermiştir. Ayrıca, öğretmen adaylarının zihinlerinde "sıkı istifleme" ve "birim hücre" modelinin de yer aldığ 1 belirlenmiştir. Bu sonuç öğretmen adaylarının üniversite düzeyindeki derslerde öğrendiklerinin zihinlerindeki metallik yapı ile ilgili önemli etkisinin olduğunu ama zihinlerinde farklı modelleri birleştirerek hibrit modeller de oluşturabildiklerini göstermiştir (Nakiboğlu, 2019). Metalik bağlanmanın öğrenilmesi ve öğretim 
sırasında öğrencilerde farklı zihinsel modellerin gelişmesine yönelik sorunların kaynağına bakıldığında, bu duruma öncelikle metalik bağlanma konusunun soyut yapısının neden olduğu görülebilir. Ancak diğer önemli bir nokta ise gerek metalik bağlanma ve gerekse kimyasal bağlanma ögretilirken birçok farklı modellerin ve metaforların kullanılmasının da önemli bir rolü olduğu söylenebilir. Metalik bağ açıklanırken bilimsel modellere alternatif olarak geliştirilen "elektron denizi" metaforu ile "elektron bulutu" metaforu konu anlatımı sırasında öğretmenler tarafından kullanılır ve ayrıca ders kitaplarında da bu metaforlara ait çizimler yer alır. Bu durum öğrencilerin zihinlerinde metalik bağlanmanın temelinde yer alan elektrostatik etkileşim yerine farklı metoforların yer almasına neden olabilir.

Yapılan çalışmalar incelendiğinde metafor ve analoji kelimelerinin birbiri yerine kullanıldığ görülmektedir. Hatta bazı çalışmalarda öğrencilerin benzeşimlerine yönelik veri toplanmasına rağmen, analizlerin metaforlara yönelik yapıldığı görülür. Metafor ve analoji kavramı birbirinden biçimsel açıdan farklılık içerir. Her ne kadar her ikisinde de benzetmeden yola çıkılsa da metafor, "mecaz" anlamına gelmekte olup bir şeyi başka bir şeye göre üstü kapalı olarak anlamlandırmak anlamına gelmektedir (Lakoff ve Johnson 2005; 25 akt. Köseoğlu, 2017). Bazen kelimelerin yetersiz kaldığ ya da anlatımın kuvvetlendirilmesi gerektiğinde metaforlar önemli bir iletişim aracı olabilirler (Nakiboğlu \& Yıldırım, 2019). Analoji ise "benzeşim" anlamına gelmekte olup iki alanı açık bir şekilde karşılaştırır. Metaforlar olguları karşılaştırmayı üstü kapalı bir şekilde yaparken analojilerde "benzer" kelimesi ile karşılaştırma açıkça ifade edilir. Bu nedenle bu iki kavramı kullanırken dikkatli olmak gerekir. Bütün bu açıklamalar doğrultusunda öncelikle bu çalışmada metalik bağa yönelik öğrencilerin hem metafor hem de analojileri araştırılarak farklandırılmaya çalışılmıştır. Diğer taraftan ortaöğretim ögrencilerinin metalik bağ kavramını nasıl algıladıklarının, metalik bağı açıklarken metaforları kullanıp kullanmadıkları ve zihinlerinde metalik bağı ne ile özdeşleştirdiklerinin anlaşılması oldukça önemlidir. Bu düşüncelerden hareketle araştırmanın amacı ve araştırma soruları aşağıda verilmiştir.

\section{Çalışmanın Amacı ve Problemleri}

$\mathrm{Bu}$ çalışma kapsamında ortaöğretim öğrencilerinin metalik bağ/metalik bağlanma konusunun öğretimi sonrası metalik bağ kavramını ve metalik bağlanmayı nasıl algıladıkları, metalik bağı tanımlamada kullandıkları metaforlar ile metalik bağlanma için hangi tür benzeşimleri kullandıklarının belirlenmesi amaçlanmıştır. Bu amaç doğrultusunda çalışmanın problemleri şunlardır:

1. Ortaöğretim öğrencileri metalik bağ/metalik bağlanmayı deneyimleri doğrultusunda nasıl algilamaktadırlar?

2. Ortaöğretim öğrencilerinin metalik bağ/metalik bağlanmayı tanımlarken kullandıkları kavramsal metaforlar nelerdir?

3. Ortaöğretim öğrencilerinin metalik bağ/metalik bağlanma ile ilgili benzeşimlerinin kategori ve türleri nelerdir?

\section{Yöntem}

\section{Çalışmanın Modeli}

Bu çalışmada nitel araştırma yöntemlerinden fenomenografi kullanılmıştır. Marton (1981) tarafından deneyimlerin tanımı, analizi ve anlaşılmasını amaçlayan araştırmalar fenomenografik çalışma olarak adlandırılmıştır. Fenomenografik araştırmada temel amaç, belirli bir olgu ile ilgili algıları ortaya çıkarmak ve bu algıları kavramsal kategorilere göre sınıflandırmaktır.

Algı, gelen bilgileri işleyerek belirli bir yapı ve organizasyona sokma işlemi olarak ifade edilir ve bir düşüncenin oluşabilmesi sırasında bilişsel bir süreç yaşanması gerekmekte olup bu bilişsel sürecin ilk adımı algılamadır (Beyoğlu, 2015). Algı, dış dünyadan gelen uyarıların, zihinsel olarak yorumlanması olarak da tanımlanabilir. Algılar; ne gördüğümüzü, nasıl yorumladığımızı, neye inandığımızı, nasıl davrandığımızı bize göstermektedir (Bakan \& Kefe, 2012).

Marton (2005), fenomenografinin insanlar ve çevrelerindeki dünya arasındaki ilişkileri ile ilgilendiğini (Marton, 2005, s. 143) ifade ederek fenomenografi çalışmalarında çıkış noktasının her zaman ilişkisel olduğunu ve fenomenografinin ilişkisel, deneyimsel, içerik odaklı ve niteliksel tanımlamalar sağladığını belirtmiştir. Fenomenografik analizde, bireylerin araştırılacak olan fenomenle ilgili olarak ortaya attıkları tanımlar kategorilere ayrılarak fenomeni deyimlerine bağlı olarak nasıl algıladıkları ortaya çıkarılır. Bu işlem sırasında içerik analizden yararlanılır. Bu şekilde oluşturulan kategori ya da 
temalar sonucunda elde edilen fenomenlerin farklı yollardan nasıl anlaşıldığ 1 nitel olarak açıklanır ve bunun sonucunda ortaya çıkan kategorilere göre farklı kavrayışlar sistematik olarak ayrılır (Ashworth \& Lucas, 1998).

\section{Çalışmanın örneklemi}

Çalışmanın örneklemini 2018-2019 eğitim öğretim yılında öğrenim gören 184 kız ve 113'ü erkek olmak üzere toplam 297 onuncu sınıf öğrencisi oluşturmaktadır. Çalışma grubunun belirlenmesinde seçkisiz olmayan örnekleme yöntemlerinden uygun örnekleme yöntemi kullanılmıştır (Büyüköztürk, Kılıç Çakmak, Akgün, Karadeniz \& Demirel, 2008). Çalışmanın fenomenografik bir araştırma olması nedeniyle örneklemin farklı deneyimlere sahip öğrenci guruplarından oluşturulması oldukça önemlidir. Bu nedenle örneklem oluşturulurken maksimum çeşitlemeye de dikkat edilerek, üç farklı okul türü olan anadolu lisesi, fen lisesi ve meslek lisesindeki öğrenciler örnekleme alınmıştır. Ayrıca örneklemde yer alan anadolu liseleri farklı akademik başarıya sahip okullardan seçilerek maksimum çeşitlilik sağlanmaya çalışılmıştır. Örneklemde yer alan öğrencilerin okul türlerine göre dağılımı Tablo 1 'de sunulmuştur.

Çalışmada yer alan okulların isimleri saklı tutulmuş ve okul türleri için aşağıda açılanan kodlar kullanılmıştır. AL1: Akademik başarısı oldukça yüksek bir anadolu lisesi; AL2: Akademik başarısı düşük bir anadolu lisesi; AL3: Akademik başarısı orta düzeyde olan bir anadolu lisesi; FL: Fen lisesi; ML: Meslek Lisesi

Tablo 1.

\begin{tabular}{cccc} 
Ortaögretim Öğrencilerinin & \multicolumn{3}{c}{ Okul Türlerine Göre Dă̆ılımı $(N=297)$} \\
\hline Okul Türü & K & E & Toplam \\
& 24 & 26 & 50 \\
AL1 & 21 & 22 & 43 \\
AL2 & 36 & 23 & 59 \\
Fen Lisesi & 37 & 42 & 79 \\
AL3 & 66 & - & 66 \\
Meslek Lisesi & 184 & 113 & 297 \\
Toplam & & & \\
\hline
\end{tabular}

\section{Veri Toplama Aracı ve Verilerin Toplanması}

Çalışmadaki veriler geniş bir proje kapsamında toplanmış olması nedeniyle bu çalışmada sadece metalik bağlanma ile ilgili kesitine yönelik bulgularına yer verilmiştir. Projenin tamamı için iki sayfalık ve iki aşamalı bir ölçme aracı araştırmacılar tarafından geliştirilmiş ve verilerin hepsi bir seferde toplanmıştır. Veri toplama aracı geliştirilirken ilk olarak alanyazın taranarak öğrencilerin algı, metafor ve benzeşimlerinin birlikte incelendiği bir çalışma olup olmadığına bakılmıştır. Bu tür bir çalışmaya rastlanmayınca kimyasal bağ ve bağ türlerine yönelik diğer çalışmalar incelenmiştir. $\mathrm{Bu}$ inceleme sonucunda öğrencilerin algısının ortaya çıkarılmasının en iyi yollarından birisinin öğrencilerden kimyasal bağ ve bağ türlerini doğrudan tanımlamalarının istenmesi sonucuna ulaşılmıştır. Bu düşünceden hareketle bağ tanımlamaları ile ilgili ölçme aracının ilk sayfasında yer alan sorular hazırlanmıştır. İki kimya öğretmeni ile yapılan görüşme ile ölçme aracının kapsam geçerliliği sağlanmıştır. Daha sonra bir pilot uygulama gerçekleştirilerek, ölçme amacının çalışmanın amacına hizmet edip etmediği incelenmiştir. Pilot verilerin analizi sonucunda, bu tür bir ölçme aracı ile araştırma sorularına yanıt bulunabileceği anlaşılmıştır. Ayrıca soruların sade ve yalın olması nedeniyle, öğrenciler tarafindan doğru şekilde algılandığı belirlenmiştir. Bu şekilde geliştirilen veri toplama aracının ilk sayfasında, bağ kavramı ve bağ türleri ile bağ enerjisinin tanımlarının sorulduğu altı açık uçlu soru yer almaktadır. İkinci sayfada, ilk sayfadaki kavramları neye benzettiklerine yönelik altı boşluk doldurma sorusu yer almaktadır. Veri toplama aracının bu şekilde hazırlanmasındaki amaç, ilk olarak öğrencilerin metalik bağ algıları ve tanımlamada kullanılan metaforlar açık uçlu bir soru ile belirleyebilmek ve sonrasında "metalik bağ ..... benzer" şeklinde bir boşluk doldurma sorusu ile öğrencilerin metalik bağ ile ilgili benzeşimlerini belirleyebilmektir. Öğrencilerden metalik bağa yönelik benzeşim yazmalarından sonra, yaptıkları benzeşimlerine yönelik bir gerekçe istenmiştir. Böylece bu açıklamalar, analizler sırasında tema oluşturmanın doğru şekilde yapılmasına yardımcı olmuştur. 
Veri toplamada etik kurallar dikkate alınarak öncelikle Balıkesir İl Millî Eğitim Müdürlügü̈’nden gerekli izinler alınmıştır. Ayrıca öğrencilere uygulama öncesi açıklama yapılarak çalışmaya katılım konusunda istekli olanlar çalışmaya dâhil edilmiş̧ir.

\section{Verilerin analizi}

Marton (2005), fenomenografik araştırma analizi için kesin teknikler olmadığı çünkü insanların belirli fenomeni deneyimlediklerini veya kavramsallaştırdıklarını, niteliksel olarak farklı yolları bulmanın keşif gerektirdiğini belirtmiştir. Bu nedenle ilk sorunun analizinde öncelikle veriler ayıklanarak metalik bağ tanımlamasına uyan ve uymayan ifadelerin seçimi yapılmıştır. Daha sonra temalar oluşturularak, oluşturulan temaların ölçütleri belirlenmiş ve bütün öğrenci ifadeleri tekrar tekrar gözden geçirilerek hangi ifadenin hangi tema içinde yer alacağına karar verilmiştir.

Birinci sorunun metaforlar açısından analizi ile ikinci sorunun analizi içerik analizi kullanılarak gerçekleştirilmiştir. İçerik analizinde temel amaç, toplanan verileri açıklayabilecek kavramalara ve ilişkilere ulaşmaktır İçerik analizinde verilerin işlenmesi aşamasında araştırmacı tarafından önce veri incelenir ve kodlanır. Veriler kodlanırken araştırma problemine göre önemli olan kavramlar ve temalar kullanılır (Yıldırım \& Şimşek, 2008).

Metafor analizinde öğrenci ifadelerinin metalik bağın örtük şekilde yapılan benzeşimi dikkate alınmıştır. İkinci sorunun analizinde önce öğrencilerin açık şekilde yaptıkları benzeşimleri listelenmiş ve daha sonra bu benzeşimler belirli kavramsal kategoriler altında toplanmıştır. Nitel yöntemle analiz edilen veriler, örneklemin yeterli olması nedeniyle nicel olarak frekans ve yüzde şeklinde ifade edilmiştir.

Analizin güvenirliği şu şekilde sağlanmıştır: Ölçütlere, her iki yazar tüm kâğıtları birlikte inceleyip karar verdikten sonra birinci sorunun analizi ilk olarak ikinci yazar tarafından yapılmış ve çelişkili kalan durumlar konu alanı uzmanı birinci yazar ile tartışılarak analiz kategorileri belirlenmiştir. Sonra tüm ifadeler her iki yazar tarafından tekrar incelenerek kategoriler içine yerleştirilmiştir. Daha sonra birinci yazar metalik bağ teorilerini, metalik bağa yönelik metaforları ve bu konuda yapılan çalışmaları (Nakiboğlu, 2019; Taber, 2003) dikkate alarak temaları ve tabloları oluşturmuştur. Her iki yazar tüm kağıtları bağımsız olarak analiz etmiş ve sonunda iki analiz sonucu birleştirilerek analiz sonuçlandırılmıştır. Analizciler arasında ilk analiz sonucunda farklı olan yerlerin tamamı iki araştırmacı tarafından birlikte tekrar analiz edilmiştir. Ayrıca çalışma verileri 2 ay sonra iki araştırmacı tarafından tekrar analiz edilmiş ve analizlerin birbiri ile tamamen uyumlu olduğu sonucuna ulaşı1mıştır.

\section{Bulgular}

Bulgular her bir araştırma problemine yanıt oluşturacak şekilde ayrı başlıklar halinde aşağıda sunulmuştur.

\section{Metalik Bağ/Metalik Bağlanmanın Algılanmasına Yönelik Bulgular}

Ortaöğretim öğrencileri metalik bağ/metalik bağlanmayı nasıl algıladıklarına yönelik birinci araştırma problemine yanıt bulmak üzere öğrencilerin metalik bağ kavramına yönelik tanımları analiz edilmiştir. $\mathrm{Bu}$ analize ait bulgular Tablo 2'de sunulmuştur.

Tablo 2 incelendiğinde, öğrencilerin metalik bağlanmayı algılarının 6 tema altında toplandığı görülür. İlk metalik bağ algısı, metalik bağlanmanın "metaller arasında oluşma"sı ile ilgili olduğu görülmektedir. Öğrencilerin \% 65 gibi büyük bir kısmı metalik bağlanmanın iki veya daha fazla metal arasında oluştuğu şeklinde bir yanlış algıya sahip oldukları görülmektedir. Bu algı altında toplanan ifadeler incelendiğinde en çok tekrar edilen ifadenin "Metallerin kendi aralarında oluşturduğu bağdır." ifadesi olduğu ve örneklemde yer alan bütün okul türlerindeki öğrencilerin tanımlamalarında bu ifadenin yer aldığı görülür. Bazı öğrenciler "İki metalin birbiriyle birleşmesi sonucu oluşur." ifadesini kullanmaktadır. Bu tür ifadeler metalik bağlanmanın "aynı metal atomları arasında oluşan bir bağ" olma algısının öğrencilerin büyük bir çoğunluğunda oluşmadığını da göstermektedir. 
Tablo 2

Metalik Bă̆ İle İlgili Öğrenci Algılarının Analizi (N=297)

\begin{tabular}{|c|c|c|c|c|c|c|c|c|c|}
\hline \multirow[t]{2}{*}{ Tema } & \multirow[t]{2}{*}{ İfadeler } & \multirow{2}{*}{$\begin{array}{c}\text { AL1 } \\
\text { f }\end{array}$} & \multirow{2}{*}{$\begin{array}{c}\text { AL2 } \\
\mathbf{f}\end{array}$} & \multirow{2}{*}{$\begin{array}{c}\text { FL } \\
\mathbf{f}\end{array}$} & \multirow{2}{*}{$\begin{array}{c}\mathbf{A L 3} \\
\mathbf{f}\end{array}$} & \multirow{2}{*}{$\begin{array}{c}\text { ML } \\
\mathbf{f}\end{array}$} & \multicolumn{3}{|c|}{ Toplam } \\
\hline & & & & & & & f & f & $\%$ \\
\hline \multirow[t]{10}{*}{1} & $\begin{array}{l}\text { Metallerin kendi aralarında } \\
\text { oluşturduğu bağdır. }\end{array}$ & 28 & 26 & 5 & 25 & 17 & 101 & 193 & 65.0 \\
\hline & $\begin{array}{l}\text { Metaller arasındaki ya da birden } \\
\text { fazla atomu bir arada tutan bağdır. }\end{array}$ & 5 & - & 23 & 7 & 15 & 50 & & \\
\hline & $\begin{array}{l}\text { İki metalin birbiriyle birleşmesi } \\
\text { sonucu oluşur. }\end{array}$ & 1 & - & - & 9 & - & 10 & & \\
\hline & $\begin{array}{l}\text { Metal ve metal iyonlarını } \\
\text { birleşmesidir. }\end{array}$ & 1 & 8 & - & 1 & - & 10 & & \\
\hline & $\begin{array}{l}\text { İki metal elementinin yaptığı bağa } \\
\text { denir. }\end{array}$ & 3 & - & 1 & 3 & - & 7 & & \\
\hline & $\begin{array}{l}\text { İki metal arasında olur. Alaşıma da } \\
\text { denir. }\end{array}$ & - & - & 1 & 4 & - & 5 & & \\
\hline & İyon, iki elementin bağıdır. & - & 3 & - & 1 & & 4 & & \\
\hline & Metallerin tepkiye girmesine denir. & - & 2 & - & 1 & - & 3 & & \\
\hline & $\begin{array}{l}\text { Metallar arasindan gerçekleşen iyon } \\
\text { denizi sayesinden oluşan bağdır. }\end{array}$ & - & - & 1 & - & - & 1 & & \\
\hline & Metal-metal arasındaki etkileşimdir. & 1 & - & - & - & 1 & 2 & & \\
\hline \multirow[t]{3}{*}{2} & $\begin{array}{l}\text { İki metal arasında olur. Alaşımda } \\
\text { denir. }\end{array}$ & - & - & 5 & 4 & - & 9 & 16 & 5.4 \\
\hline & $\begin{array}{l}\text { Alaşımlar arasında olur. } \\
\text { Metalik bağ çelik, demir gibi }\end{array}$ & 7 & - & - & - & - & 7 & & \\
\hline & $\begin{array}{l}\text { maddelerin alaşım oluşturmasını } \\
\text { sağlayan bağdır. }\end{array}$ & - & 1 & - & - & - & 1 & & \\
\hline \multirow[t]{2}{*}{3} & Ametal ile metal arasındaki bağdır. & 1 & - & - & - & 2 & 3 & 6 & 2.0 \\
\hline & $\begin{array}{l}\text { Ametallerin elektron ortaklaşması ile } \\
\text { yaptığı bağdır. }\end{array}$ & 1 & 2 & - & - & - & 3 & & \\
\hline \multirow[t]{2}{*}{4} & Fiziksel bağdır & 2 & - & - & & - & 2 & 4 & 1.4 \\
\hline & Metal-metal arasındaki etkileşimdir. & 1 & - & - & - & 1 & 2 & & \\
\hline \multirow[t]{2}{*}{5} & $\begin{array}{l}\text { Metallerin elektron bulutuyla birlikte } \\
\text { yaptığı bağdır. }\end{array}$ & 2 & - & - & - & - & 2 & 3 & 1.0 \\
\hline & $\begin{array}{l}\text { Metal atomlarının ortamdaki } \\
\text { elektronu ortak çekimiyle oluşur. }\end{array}$ & 1 & - & - & - & - & 1 & & \\
\hline \multirow[t]{2}{*}{6} & $\begin{array}{l}\text { Metallar arasindan gerçekleşen iyon } \\
\text { denizi sayesinden oluşan bağdır. }\end{array}$ & - & - & 2 & - & - & 2 & 3 & 1.0 \\
\hline & $\begin{array}{l}\text { Elektron deniziyle ile alakalı } \\
\text { alaşımlara örnek verilir. }\end{array}$ & 1 & - & - & - & - & 1 & & \\
\hline
\end{tabular}

1: Metaller arasında bağ oluşumu, 2: Alaşım, 3: İyonik/Kovalent bağ 4: Etkileşim, 5: Elektron, 6: Elektron denizi.

İkinci algı, metalik bağlanmanın alaşım oluşturduğu ve metalik bağlanmanın alaşımlar arasında olduğuna yönelik bir alg1 olup ilk algı ile de ilişkilidir. Öğrencilerin \% 5.7'si metalik bağ1 yine metaller arasında ya da farklı elementler arasında oluştuğu şeklinde düşünmektedir. Bu algı ile ilgili tekrarlanan bir ifade "Alaşımlar içinde oluşan bağdır." ifadesinden bu durum açıkça görülmektedir. Üçüncü algı, metalik bağlanmanın diğer bağ türleri ile karıştırılmasına dayanır. Öğrencilerin yanıtları incelendiğinde metalik bağlanmayı kovalent ve iyonik bağlanmaya benzer tanımlamalar yapmışlardır. Dördüncü algı ise metalik bağın moleküller arası etkileşimler gibi düşünülmesi olan "Metal-metal arasındaki etkileşimdir." şeklinde olduğu görülür. Ayrıca öğrenciler "metalik bağın fiziksel bir bağ olduğuna yönelik ifadesi de bu düşünceyi destekler niteliktedir.

Beşince ve altıncı algılar, metalik bağın lise ders kitaplarında yapılan tanımlamaları ile örtüşen ifadeler olup her iki kategori de elektron denizi modeline dayanır. Ancak beşinci kategoride doğrudan elektron denizi metaforuna dayanan bir açıklama yapılmamış metalik bağ oluşumu metal iyonları arasında olduğu veya elektron bulutları arasındaki bağ olduğu söylenmiştir. $\mathrm{Bu}$ alg1, lise düzeyinde öğretilenlere göre doğru kabul edilebilecek algılamalar olup bu ifadeleri sadece akademik başarısı yüksek anadolu lisesi öğrencilerinin yazdığı Tablo 2'den görülür. Altıncı kategori her ne kadar elektron denizine dayansa da öğrencilerin bunu metaller arasında olarak düşündüğü ifadelerinden 
görülmektedir. Akademik başarısı yüksek anadolu lisesi öğrencilerinden bir tanesi bunun alaşımlar için olduğunu düşündüğü "Elektron deniziyle alakalı alaşımlara örnek verilir." Şeklindeki ifadesinden anlaşılmaktadır. Fen lisesine devam eden iki öğrencinin de "Metaller arasından gerçekleşen iyon denizi sayesinde oluşan bağdır" şeklinde açıklamalarından metalik bağı metaller arasında bir bağ olarak düşündükleri görülmektedir.

\section{Metalik Bă̆/Metalik Bağlanmanın Tanımlanmasında Kullanılan Kavramsal Metaforlara Yönelik Bulgular}

Ortaöğretim öğrencilerinin metalik bağ/metalik bağlanmayı tanımlarken kullandıkları kavramsal metaforların neler olduğuna yönelik araştırma problemine yanıt bulmak üzere öğrencilerin metalik bağ tanımları metaforlar açısından analiz edilmiştir. $\mathrm{Bu}$ metaforların oluşumunda genel olarak ders kitaplarında yer alan "elektron denizi", "elektron bulutu", "alış-veriş", "iyon denizi" ve "etkileşim" metaforlarının öğrenci ifadelerinde yer alıp almadığı yönünde analizler yapılırken, bunların dışında rastlanan metaforik ifadeler varsa bunlar da analize dahil edilmiştir. Öğrencilerin metalik bağ tanımlaması sırasında kullandıkları metaforlara yönelik bulgular Tablo 3'de verilmiştir.

Tablo 3

Öğrencilerin Metalik Bă̆ İle İlgili Kavramsal Metaforları

\begin{tabular}{|c|c|c|c|c|c|}
\hline \multirow{2}{*}{ Metaforlar } & \multirow{2}{*}{ Örnek İfadeler } & \multirow{2}{*}{$\begin{array}{c}\mathrm{Kuz} \\
\mathrm{f}\end{array}$} & \multirow{2}{*}{$\begin{array}{c}\text { Erkek } \\
\quad f\end{array}$} & \multicolumn{2}{|c|}{ Toplam } \\
\hline & & & & $\mathrm{f}$ & $\%$ \\
\hline Etkileşim & Metal arasındaki etkileşimdir. Güçlü etkileşimdir. & 3 & - & 3 & 1.01 \\
\hline Güçlü Bağ & Metal atomları arasındaki güçlü bağlardır. & 3 & - & 3 & 1.01 \\
\hline Elektron denizi & Elektron denizi ile alakalı alaşımlara örnek verilir. & - & 2 & 2 & 0.67 \\
\hline Elektron bulutu & $\begin{array}{l}\text { İki ametalin birbiri arasında yaptığı bağ türüdür. } \\
\text { Elektron bulutu şeklinde oluşur. }\end{array}$ & - & 1 & 1 & 0.3 \\
\hline İyon denizi & $\begin{array}{l}\text { Metaller arasında gerçekleşen iyon denizi sayesinde } \\
\text { oluşan bağ. }\end{array}$ & 1 & - & 1 & 0.3 \\
\hline Alışveriş & İki metal madde arasındaki alışverişe denir. & 1 & - & 1 & 0.3 \\
\hline
\end{tabular}

Tablo 3 incelendiğinde; öğrencilerin "metalik bağ" tanımlamasında 6 farklı kavramsal metafor kullandıkları görülmektedir. 'Etkileşim' metaforu öğrencilerin metalik bağı bir etkileşim olarak düşündüğünü gösterirken, "elektron denizi", "iyon denizi" ve "elektron bulutu" ders kitaplarında metalik bağ açıklanırken kullanılan kavramsal metaforlardır. Bunların yanında "alış-veriş" metaforu genel olarak bağ türleri açıklanırken kullanılan elektron alışverişi metaforunu andırmaktadır. Güçlü bağ metaforu, bağ sınıflamaları yapılırken bağları zayıf ve güçlü şekilde sınıflandırılması ile ilgili genel bir ifadedir.

\section{Metalik Bă̆ Benzeşim Kategorileri, Türü ve Sayısına Yönelik Bulgular}

Öğrencilerin metalik bağ ile ilgili benzeşimlerinin kategorileri, tür ve sayısının belirlenmesi amacıyla ilk önce her öğrencinin ikinci soruda metalik bağa yönelik yazdıkları benzeşimler frekans dağılımına göre listelenmiş ve daha sonra benzeşimler sınıflandırılarak kategoriler oluşturulmuştur. Metalik bağ ile ilgili öğrencilerin 104 adet benzeşim yazdığı görülse de benzeşim kategorileri oluşturulurken bunlardan sadece benzeşime yönelik açıklama yapılanlar dikkate alınmıştır. Açıklama yapılan benzeşimlerin içerik analizi sonucunda metalik bağ ile ilgili belirlenen kategoriler, benzeşim türü ve bu benzeşimlerin sayısal dağılımları Tablo 4'te verilmiştir.

Tablo 4'te yer alan benzeşim kategorileri incelendiğinde, kategorilerin altı başlık altında toplandığı görülür. Bu altı kavramsal kategoride toplam 54 çeşit benzeşim türü yer almaktadır. En fazla benzeşimin yer aldığı kategori "bir arada tutma" kategorisidir. Bu kategorinin oluşturma ölçütü verilen hedef kavramın metal atomlarını bir arada tutması gibi benzetilen nesnelerin de bir şeyleri bir arada tutması olarak düşünülmesidir. Tablo 4'den görüldüğü gibi "bir arada tutma" kategorisine baktığımızda 19 farklı benzeşimin yer aldığı ve bunların toplam sayısının 30 olduğu görülür. $\mathrm{Bu}$ kategorinin en fazla yazılan benzeşim olan "mıknatıs" ve "kiraz" benzeşimleri için birer öğrenci ifadesi aşağıda verilmiştir. 
"Metalik bağ kiraza bezer, çünkü ikisi metalik bağ yapıyorlar gibi"

"Metalik bağ mıknatısa benzer, çünkü iki metali bir arada tutar."

Burada benzeşimler öğrencilerin metalik bağ ile iki metalin bir arada tutulduğu ya da bağ yapıyor gibi bir yanlış kavramaya sahip olduğunu göstermektedir. Benzer düşünce farklı öğrenciler tarafindan da ifade edilmektedir.

Tablo 4

Öğrencilerin Metalik Bă̆ İle İlgili Benzeşim Kategorileri, Türü Ve Sayısı

\begin{tabular}{|c|c|c|c|}
\hline Kategoriler & Benzeşim türü (analoji) & $\begin{array}{l}\text { Benzeşim Türü } \\
\text { Sayısı }\end{array}$ & $\begin{array}{c}\text { Benzeşi } \\
\text { m (f) }\end{array}$ \\
\hline $\begin{array}{l}\text { Bir arada } \\
\text { tutma/olma, } \\
\text { çekim }\end{array}$ & $\begin{array}{l}\text { Miknatıs (5), Kiraz (4), Evlilik (2), Zincir (2), Aile } \\
\text { (2), Vagon (2), Mandal (1), Toka (1), Spartalı (1), } \\
\text { Kalkan-kılıç (1), Toplum (1), Akrep-yelkovan (1), } \\
\text { Organ (1), Kardeş (1), Ayakkabı bağı (1), Aşıllanma } \\
\text { (1), Kaynak (1), Üzüm (1), Kardeş (1) }\end{array}$ & 19 & 30 \\
\hline Kuvvet/Güç & $\begin{array}{l}\text { İkizler (1), İp (1), Zincir (1), Öğrenci (1), Para (1), } \\
\text { Fermuar (1), Örümcek Ağ }(1), \text { Elektriklenme (1), } \\
\text { Demir çubuk (1), Cam (1), }\end{array}$ & 10 & 10 \\
\hline Metal olma & $\begin{array}{l}\text { Bor (4), Metal (4), Demir (2), Lehim (1), İyonik } \\
\text { bağ (1), Bakır (1), Altın (1), Gümüş (1), Kaynak (1) }\end{array}$ & 9 & 16 \\
\hline Metal İçerme & $\begin{array}{l}\text { Bilezik (2), Çelik (1), Pirinç (1), Bakır (1), Alaşım } \\
\text { (1), Tencere (1), Masa (1) }\end{array}$ & 7 & 8 \\
\hline Özellik & $\begin{array}{l}\text { Elektrik (2), Miknatıs (1), Nar (1), Para (1), Kasiyer } \\
\text { (1), Kapitalizm (1), Bulut (1) }\end{array}$ & 7 & 8 \\
\hline Benzer olma & İyonik bağ (2), Arkadaş (1) & 2 & 3 \\
\hline TOPLAM & & 54 & 75 \\
\hline
\end{tabular}

İkinci kategori olan "kuvvet/güç" kategorisi metalik bağlanmanın kuvvetli veya zayıf oluşuna yönelik öğrenci benzeşimlerini içermektedir. Bu kategoride 10 farklı benzeşim türü yer aldığ 1 ve bunların toplam sayısının da 10 olduğu görülür. Bu kategori oluşturulurken açıklamalarda bağ oluşumunun veya ortaya çıkan bağlanmanın güçlü olduğunun ifade edildiği belirlenmiştir.

"Metalik bağ ikizlere benzer. Çünkü neredeyse birebir aynı özellikte olan maddeler bağ yapar.

Bunlar da çok güçlüdür. Birlikte çok kuvvetlidirler.”

$\mathrm{Bu}$ öğrenci açıklamasına bakıldığında, öğrencinin metalik bağın aynı metal atomlarından oluştuğunun ve metalik bağlanmanın güçlü bir bağlanma olduğunun farkında olduğu görülmektedir. Bu kategoriye ait bir başka açıklama da şöyledir.

"Metalik bağ zincire benzer. Çünkü çok kuvvetlidir."

Tablo 4'den görüldüğü gibi, üçüncü kategori "metal olma" kategorisi olarak etiketlenmiştir. Bunun nedeni bu kategoride yer alan benzeşimlerin metal olduğu ve bu nedenle metalik bağa benzediği öğrenciler tarafından benzetilmiş olmasıdır. Örneğin bu kategoride yer alan demir ve diğer elementler için aşağıdakine benzer bir ifade kullanılmıştır.

"Metalik bağ demire benzer. Çünkü (demir) metaldir. “

"Metalik bağ altına benzer. Çünkü metaldir."

"Metalik bağ metallere benzer. Çünkü metallerden oluşur."

Diğer bir kategori olan "metal içerme" kategorisi, "metal olma" kategorisinden farklı olarak ele alınmıştır. Çünkü "metal olma" kategorisinde benzetilen doğrudan metal olarak alınırken "metal içerme" kategorisinde benzetilen madde veya nesnenin metalik bağlarla oluşan maddelerin metal içerdiğinin düşünülmesidir. Bu kategoride 7 farklı benzeşimin yer aldığ 1 ve bunların toplam sayısının 8 olduğu görülür. Tablo 4'den görüldüğü gibi "metal içerme" kategorisine baktığımızda bu kategoride yazılanların metal içeren alaşım örnekleri veya metallerden yapılan malzemeler olduğu görülür. "Bilezik" benzeşiminde bulunan iki öğrencinin ifadesinden bu durum açıkça görülmektedir. 
"Metalik bağ bileziğe benzer. Çünkü metaller eritilerek karıştırılır.”

Beşinci kategori olan "özellik” kategorisinde 7 benzeşim bulunur. Bunların toplam sayısı sekizdir. Bu kategoride yapılan benzeşimler metallerin özellikleri ile eşleştirilmeye çalışılmıştır. Aşağıda bu benzeşime yönelik örnek ifadeler yer almaktadır.

"Metalik bağ elektriğe benzer. Çünkü metaller elektriği iyi iletir."

"Metalik bağ mıknatısa benzer. Çünkü metaller mıknatısı çok iyi çeker."

"Metalik bağ nara benzer. Çünkü aynı atomlar var."

Bu kategoride yer alan iki benzeşim "kasiyer" ve "kapitalizm" ise metallerin elektron verme özelliğine benzetilmiştir. Örneğin kasiyer benzeşimine yönelik öğrenci ifadesi şu şekildedir.

"Metalik bağ kasiyere benzer. Çünkü hep para veriyor. Metalik bağ ise elektron veriyor."

Altıncı kategori olan "benzer olma" kategorisinin oluşturulması sırasında izlenen yol, metallerin elektron verme özelliği ile ilişki kurulmuş olmasıdır. Bu kategoriye yönelik iki öğrenci ifadesi aşağıda yer almaktadir.

"Metalik bağ iyonik bağa benzer. Çünkü metal benzer."

"Metalik bağ arkadaşa benzer. Çünkü metaller gibi birbirimize benzeriz."

Bu ifadelerden ilkinde öğrencinin metalik ve iyonik bağın her ikisinde de metallerin yer alması yönü ile bir benzerlik kurduğu görülmektedir.

\section{Sonuçlar ve Öneriler}

Çalışmada metalik bağ kavramının ortaöğretim öğrencileri tarafindan altı farklı şekilde algılandığ1 sonucuna ulaşılmıştır. İlk iki algı metalik bağlanmanın "metaller arasında oluşma" ve "alaşımlar arasında olma" algılarıdır. Bu sonuçtan öğrencilerin metalik bağlanmayı aynı metal atomlarının birbirine bağlanması ile oluşan metalik örgü düşüncesi yerine farklı metallerin veya elementlerin arasındaki bağlanma olarak düşündüğü ve bu nedenle bu şekilde düşünen öğrencilerin metalik bağlanmayı yanlış algıladıkları söylenebilir. Bu yanlış kavrama Nakiboğlu (2019) tarafından öğretmen adayları ile birlikte yürütülen çalışmada ulaşılan sonuçla örtüşmektedir. Nakiboğlu (2019), öğretmen

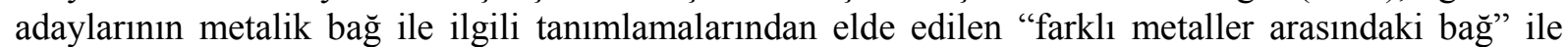
"metaller arasındaki bağ" ifadelerinin yanlış kavrama ifadesi olarak değerlendirileceğini belirtmiştir. Bu tür düşünceye sahip öğretmen adaylarının metalik bağı aynı veya farklı metaller arasında oluştuğu şeklinde bir düşünceye sahip olduklarını ifade etmiştir. Bu durum lise yıllarında edinilen bu yanlış kavramanın üniversite düzeyinde kimya dersleri almış olmalarına rağmen öğretmen adaylarında devam ettiğini gösterir. Taber (2003) öğrencilerin metalik bağlanma ile ilgili mental modellerine öğretimin etkisini incelediği çalışmasında benzer bir sonuç bulmuştur. Çalışma sonunda her ne kadar öğrencilerin metalik bağlanma ile zihinsel modellerinde öğretim ile değişiklik olsa da ilk ögrenmelerinin bu modeller üzerinde önemli etkisi olduğunu belirlemiştir (Taber, 2003). Bu nedenle ortaöğretimde bağ kavramının nasıl öğretildiği son derece önemlidir.

Üçüncü algı, metalik bağlanmanın tanımlanmasında öğrencilerin diğer bağ türlerine yönelik tanımları kullanmaları ile ilgilidir. Öğrencilerin yanıtları incelendiğinde metalik bağlanmayı kovalent ve iyonik bağlanmaya benzer tanımlamalar yaptıkları görülmüştür. Bu sonuç Teber'in (2003) çalışmasında bulduğu, öğrencilerin metallerin kovalent ve/veya iyonik bağlara sahip oldukları düşünmeleri sonucu ile örtüşmektedir. Metalik bağ ile ilgili dördüncü algı ise metalik bağın moleküller arası etkileşimler gibi düşünülmesi olan "Metal-metal arasındaki etkileşimdir." algısıdır. Bu durum kimya ders kitaplarında metalik bağın moleküller arası etkileşim olarak gösterilmesi ile ilgili olabilir. Ayrıca ders kitapları moleküller arası etkileşimleri fiziksel bağlar olarak sunmakta olup bu çalışmada öğrencilerin "metalik bağın fiziksel bir bağ olduğuna yönelik ifadesi de ders kitaplarının etkilerine yönelik düşünceyi destekler niteliktedir. Ders kitaplarının etkisi metalik bağa yönelik beşince ve altıncı algılarda da görülmektedir. Bu algılar, metalik bağın lise ders kitaplarında yapılan tanımlamaları ile örtüşen ifadeler olup her iki kategori de "elektron denizi" modeline dayanır. Ders kitapları metalik bağı açıklarken "elektron denizi” metaforuna sık sık yer verir. 
Öğrencilerin metalik bağ tanımlamalarında metalik bağ ile ilgili "metal katyonlarının çekirdekleri ve değerlik elektronları arasında" "yer alan elektrostatik etkileşime yer vermedikleri görülür. Öğrencilerin kimyasal bağlanma ve bağ türlerini elektrostatik çekim yasası ile ilişkilendirerek açıklayamaması, kimyasal bağlanma ile ilgili önemli sorunlardan birisi olup Teber'in (1998) belirttiği gibi öğrenciler kimyasal reaksiyon ve kimyasal bağ oluşumunu elektrostatik etkileşmeler yerine çoğunlukla Oktet kuralına dayandırarak açıklamaktadırlar. Nakiboğlu (2019), gerek bağ kuramının temelinde yer alan etkileşimlerin öğrenciler tarafindan tam anlaşılmaması gerekse arka arkaya birçok modelin sunulmasının öğrencilerin metalik yapı ve metalik bağ oluşumunu tam yapılandırmasına engel olduğunu belirtmiştir. $\mathrm{Bu}$ çalışmada da oldukça benzer bir sonuca ulaşılmış, öğrencilerin tanımlamaları içinde metalik bağlanma için tam doğru bir algıya rastlanmamıştır.

Öğrencilerin metalik bağ ile ilgili kullandıkları kavramsal metaforlara bakıldığında, "etkileşim" ve "güç" metaforu olduğu görülmektedir. "Etkileşim" metaforu, öğrencilerin "kimyasal bağ" tanımlamasında da kullanılan bir metafor olduğu Nakiboğlu ve Şafak (2019) tarafından gösterilmiş olup bu durum derslerde kimyasal bağların tanecikler arası etkileşimlerden oluştuğunun vurgulanmasına bağlanmıştır. Aynı sonuca metalik bağ için de ulaşılmış olması, ders kitaplarının kimyasal bağ ve etkileşim kavramlarını bir arada ve birbiri yerine kullanması ile ilgili olabilir. "Elektron denizi" metaforu ise ders kitaplarında metalik bağı açıklamada kullanılan bir metafor olmasından kaynaklanmaktadır.

Metalik bağ ile ilgili benzeşim kategorilerinin altı başlık altında toplandığı sonucuna ulaşılmıştır. En fazla benzeşimin yer aldığı kategori "bir arada tutma" kategorisi olup 19 adet farklı benzeşimin yer aldığı görülür. $\mathrm{Bu}$ kategorinin en fazla yazılan benzeşimi olan "mıknatıs" benzeşimine yapılan açıklamalara bakıldığında öğrencilerin yine metalik bağın metaller arasında bir bağ olduğu yanlış kavramasının var olduğu görülür. Diğer bir benzeşim kategorisi olan "metal olma" kategorisinde yazılan benzeşimlere bakıldığında altın, gümüş gibi metal isimlerinin yazıldığı görülür. Bu durum ögrencilerin metalleri tanıdıklarını göstermektedir. Ancak bu metal örnekleri dışında alaşım ve alaşım örneklerinin yazılması, tanımlamalarda yazılan "metalik bağın alaşımlar arasında bir bağ olduğu" düşüncesinin burada da devam ettiğini göstermektedir.

Çalışmanın sonuçlarından yola çıkarak şu önerilerde bulunulabilir.

1. Metalik bağ kavramının anlaşılması için öncelikle atom, element, iyon gibi temel kavramların iyi anlaşılması önemlidir. Bu nedenle metalik bağın öğretiminden önce öğrencilerin bu kavramları doğru bilip bilmedikleri incelenmelidir.

2. Metalik bağın öncesinde bağ oluşumundaki temel neden olan elektrostatik etkileşim anlatılmalıdır. Buna bağlı olarak elektron denizinin ve elektron bulutunun bir benzetme olduğu, esas olanın metal örgüsündeki elektrostatik çekimler olduğu vurgulanmalıdır.

3. Metalik bağın, metal-metal bağı olarak neden düşünüldüğü araştırılıp bu yanlış kavramanın oluşmaması için öğretim sırasında önlemler alınmalıdır.

4. Kimyasal bağlar kadar moleküller arası etkileşimler iyi anlatılıp konu anlatımı sırasında bağ kavramı ile karıştırılmamasına yönelik ders anlatım stratejileri geliştirilmelidir.

\section{Kaynakça}

Ashworth, P., \& Lucas, U. (1998). What is 'world' of phenomenography? Scandinavian Journal of Educational Research, 42(4), 415-431.

Bakani İ., \& Kefe, İ. (2012). Kurumsal açıdan algı ve algı yönetimi. Kahramanmaraş Sütçü İmam Üniversitesi İktisadi ve İdari Bilimler Fakültesi Dergisi, 2(1), 19-34.

Beyoğlu, A. (2015). Sanat eğitiminde alg1, görsel alg1 ve yanılsama: Victor Vsarely'nin çalışmaları üzerine bir inceleme. Trakya Üniversitesi Sosyal Bilimler Dergisi, 17(1), 333-348.

Büyüköztürk, Ş., Kılıç-Çakmak, E., Akgün, Ö. E., Karadeniz, Ş., \& Demirel, F. (2008). Bilimsel Araştırma Yöntemleri. Ankara: Pegem Yayıncılık.

Cheng, M. M. W., \& Gilbert, J. K. (2014) Students' visualization of metallic bonding and the malleability of metals. International Journal of Science Education, 36(8), 1373-1407, DOI: 10.1080/09500693.2013.867089. 
Cheng, M. M. W., \& Oon, P.-T. (2016). Understanding metallic bonding: Structure, process and interaction by Rasch analysis. International Journal of Science Education, 38(12), 1923-1944, DOI: 10.1080/09500693.2016.1219926.

Coll, R. K., \& Treagust, D. F. (2003). Learners' mental models of metallic bonding: A cross-Age study. Science Education, 87, 685-707.

Coll, R. K., \& Taylor, N. (2002). Mental models in chemistry: senior chemistry students mental models of chemical bonding. Chemistry Education: Research and Practice In Europe, 3(2), 175-184.

De Posada, J. M. (1997). Conceptions of high school students' concerning the internal structure of metals and their electric conduction: Structure and evolution. Science Education, 81, 445-467.

De Posada, J. M. (1999). The presentation of metallic bonding high school science textbooks during three decades: Science Educational reforms and substantive changes of tendencies. Science Education, 83, 423-447.

Kabapınar, F. M., \& Adik, B. (2005). Ortaöğretim 11.sınıf öğrencilerinin fiziksel değişim ve kimyasal bağ ilişkisini anlama seviyesi. Ankara Üniversitesi Eğitim Bilimleri Fakültesi Dergisi, 38(1), 123-147.

Köseoğlu, P. (2017). An analysis of university students' perceptions of the concepts of "water" and "water pollution" through metaphors. Eurasia Journal of Mathematics, Science \& Technology Education, 13(8), 4343-4350.

Marton, F. (1981). Phenomenography describing conceptions of the world around us. Instructional Science, 10, 177-200.

Marton, F. (2005). Phenomenography: A Research Approach to Investigating Different Understandings of Reality, In: R. R. Sherman and R. B. Webb (eds), Qualitative Research in Education: Focus and Methods. London and New York.

Nakiboğlu, C., \& Erol, N. (2017). Deneyimli Kimya Öğretmenlerinin Fiziksel ve Kimyasal Değişimler Konusunun Öğretimi ile ilgili Düşünceleri. MSKU Eğitim Fakültesi Dergisi, 4(1), 33-45.

Nakiboğlu, C., \& Yıldırım, Ş. (2019) 10. Sınıf Öğrencilerinin Kimyasal Bağ ile ilgili Algıları, Kimyasal Bağı Tanımlamada Kullandıkları Metaforlar ve Yaptıkları Benzeşimler. Journal of Turkish Chemical Society: Section C. 4(2), 61-80.

Nakiboğlu, C. (2019). Kimya Öğretmen Adaylarının Metalik Yapı ile ilgili Zihinsel Modelleri ve Metalik Bağ ile ilgili Kavramaları. Karaelmas Journal of Educational Sciences, 7(1), 133-144.

Redfors, A. (2001). University physics students' use of models in explanations of phenomena involving interaction between metals and electromagnetic radiation. International Journal of Science Education, 23(12), 1283-1301.

Taber, K. S. (2003). Mediating Mental Models of Metals: Acknowledging the priority of the learners' Prior learning. Science Education, 87,7 32-758.

Taber, K. S., Tsaparlis, G., \& Nakiboğlu, C. (2012). Student conceptions of ionic bonding: Patterns of thinking across three European contexts. International Journal of Science Education, 34(18), 2843-2873.

Yıldırım, A., \& Şimşek, H. (2008). Sosyal bilimlerde nitel araştırma yöntemleri (6. Baskı). Ankara: Seçkin Yayıncılık.

Bu çalışma Balıkesir Üniversitesi tarafindan 2018/144 nolu proje ile desteklenmiştir. Yazarlar destek için Balıkesir Üniversitesi'ne teşekkür ederler. 